
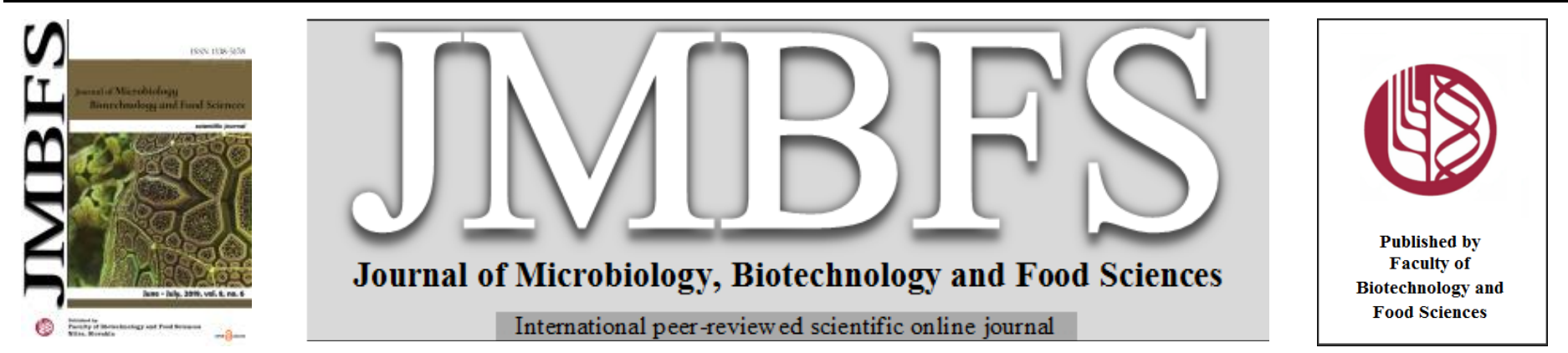

\title{
ISOLATION OF NOVEL AEROBIC DENITRIFIER AND OPTIMIZATION OF PROCESS PARAMETERS FOR BIOLOGICAL DENITRIFICATION USING RSM
}

\author{
Keshava Joshi ${ }^{1}$, Lokeshwari. $N^{1}$, Vinayaka B. Shet ${ }^{* 2}$, Srinikethan $G^{3}$, Ashwini ${ }^{1}$, Sneha ${ }^{1}$, Anusha ${ }^{1}$, Aparna $A^{4}$ \\ Address(es): Mr. Vinayaka B. Shet, \\ ${ }^{1}$ Department of Chemical Engineering, SDM College of Engineering and Technology, Dharwad-580 002, Karnataka, India. \\ ${ }^{2}$ Department of Biotechnology Engineering, NMAM Institute of Technology (V.T.U., Belagavi), Nitte-574110, Karnataka, India. \\ ${ }^{3}$ Department of Chemical Engineering, National Institute of Technology Karnataka, Surathkal-575 025, Karnataka, India. \\ ${ }^{4}$ Department of Microbiology and Molecular Genetics, Hebrew University of Jerusalem, Jerusalem- 91120, Israel.
}

*Corresponding author: vinayakabshet@gmail.com, vinayakabshet@nitte.edu.in

doi: 10.15414/jmbfs.2019.8.6.1235-1241

\section{ARTICLE INFO}

Received 20. 4. 2018

Revised 11. 1. 2019

Accepted 15. 1. 2019

Published 1. 6. 2019

Regular article

open $\partial_{\text {access }}$

\begin{abstract}
The study aimed to isolate and characterize a high efficiency novel bacterium for denitrification in waste water and also to optimize process parameters under aerobic condition. One of the bacteria chosen among four, displayed a maximum of $98 \%$ reduction of nitrate. The strain was identified as Enterobacter sp. NCCP-29 by biochemical tests and further identified based on similarity of PCR-16S rRNA using universal primers. The parameters $(\mathrm{pH}$, temperature, agitation speed, $\mathrm{C}: \mathrm{N}$ ratio) which effect the denitrification were screened using one factor at a time. The $\mathrm{pH}$, temperature and $\mathrm{C}: \mathrm{N}$ ratio exhibited significant effect on the denitrification using Enterobacter $s p$. NCCP29. The levels of these parameters were optimized using a central composite design (CCD). A maximum of $98 \%$ denitrification was achieved at $\mathrm{pH} 6.5$, temperature $30^{\circ} \mathrm{C}$ and $\mathrm{C}: \mathrm{N}$ ratio of $3: 1$. The second order model was generated and found to have a good fit with $\mathrm{R}^{2}$ value of 0.93 . Investigations revealed the ability of Enterobacter $s p . N C C P-29$ to remove nitrate under aerobic conditions.
\end{abstract}

\section{INTRODUCTION}

The major cause of depletion of acquifers and the eutrophication of rivers is the discharge of excess nitrates into the waterbodies. The nitrates being discharged of higher concentration are leading to both health and environmental effects, the main sources of nitrate comprise raw industrial waste waters, domestic waste water, land discharges animal wastes from animal farms and landfills (Vitousek et al., 1997 and Galloway et al., 2008). Therefore, many studies targeted on the nitrate removal from effluent so as to realize a suitable concentration in treated waters to be discharged into the environment. Denitrifying microorganisms are ubiquitous in nature and they have been isolated from different ecological sources. Nitrogen containing ions such as nitrite and nitrate occur widely in various process streams, like those coming back from indepth use of fertilizers. These species released to the environment can induce serious consequences, due to the potentia health effects for living system including humans (Matsuzaka et al., 2003). Hence many researchers have concentrated on the nitrate reduction from effluent so as to meet the suitable concentration level as per the standards to be discharged into the environment. Various researchers have isolated denitrifying bacteria from diverse environments such as agricultural soils, wastewater treatment plants, biofilms of long term aerobic/anoxic denitrifying reactor, deep sea sediments and have isolated potential denitrifiers from various nitrate enriched regions such as petrochemical industry effluent, greenhouse soil of agricultural land (Zumfit, 1997; Rezaee et al., 2010; Wang et al., 2013; Zhou et al., 2014, Kong et al., 2018). In this study, the isolated denitrifying bacteria from municipal waste water with high denitrification potential were identified and characterized using their morphological, biochemical properties and 16S rRNA. 16s rDNA gene sequence was used for the identification of isolated strain. The effect of isolate on nitrate reduction with different process parameters was studied. The study also analyzed with general factorial design and model variation trends for three parameters of $\mathrm{pH}$, temperature and $\mathrm{C}: \mathrm{N}$ ratio. Response surface methodology (RSM) is a tool which has substantial application in the optimization, process design and also with the enhancement of existing design (Box and Draper, 1987). This RSM tool has more practical approaches to arise from an experimental methodology with different interactive effects among the variables and also depicts the overall effects of the parameters on the process (Bas and Boyaci, 2007). In the past few years, RSM has been adopted to optimize and evaluate the interactive effects of independent factors in numerous chemical and biochemical processes (Yang and Hwang, 2003; Ahmadi et al., 2005; Aghamohammadi et al., 2007; Zinatizadeh et al., 2009). The present investigation was undertaken with the aim of isolating, screening and identification of bacteria based on biochemical and genomic characteristics for denitrifying activities. Further effect of various physicochemical parameters on denitrification were studied and were optimised for using the RSM under aerobic condition.

\section{MATERIAL AND METHODS}

\section{Materials}

Composition of nitrate rich (NR) medium was $\mathrm{NH}_{4} \mathrm{Cl}-0.3 \mathrm{~g} / \mathrm{L}, \mathrm{KH}_{2} \mathrm{PO}_{4}-1.5 \mathrm{~g} / \mathrm{L}$ $\mathrm{Na}_{2} \mathrm{HPO}_{4} .7 \mathrm{H}_{2} \mathrm{O}-7.9 \mathrm{~g} / \mathrm{L}, \mathrm{KNO}_{3}-2 \mathrm{~g} / \mathrm{L}$, disodium succinate- $27 \mathrm{~g} / \mathrm{L}, \mathrm{MgSO}_{4} .7 \mathrm{H}_{2} \mathrm{O}-5$ $\mathrm{mL} / \mathrm{L}(20 \mathrm{~g} / \mathrm{L})$.

Composition of trace element solution : $5 \mathrm{~mL} / \mathrm{L}($ EDTA, $50.0 \mathrm{~g} / \mathrm{L} ; 5.06 \mathrm{~g} / \mathrm{L}$; $\mathrm{FeSO}_{4} .7 \mathrm{H}_{2} \mathrm{O}, \mathrm{CaCl}_{2}, 5.5 \mathrm{~g} / \mathrm{L} ; \mathrm{ZnSO}_{4}, 2.2 \mathrm{~g} / \mathrm{L} ; \mathrm{CuSO}_{4} .5 \mathrm{H}_{2} \mathrm{O}, 1.57 \mathrm{~g} / \mathrm{L}$ $\mathrm{MnCl}_{2} .4 \mathrm{H}_{2} \mathrm{O}, 5.0 \mathrm{~g} / \mathrm{L} ; \mathrm{CoCl}_{2} .6 \mathrm{H}_{2} \mathrm{O}, 1.61 \mathrm{~g} / \mathrm{L}$; and $\left(\mathrm{NH}_{4}\right)_{6} \mathrm{Mo}_{7} \mathrm{O}_{24} .4 \mathrm{H}_{2} \mathrm{O}, 1.1 \mathrm{~g} / \mathrm{L}$; $\mathrm{pH} 7.2$ ) and $\mathrm{Na}_{2} \mathrm{SO}_{3}-100 \mathrm{mg} / \mathrm{L}$

Composition of bromothymol blue (BTB) medium: L-asparagine, $1 \mathrm{~g} / \mathrm{L}$; $\mathrm{KNO}_{3}, 1 \mathrm{~g} / \mathrm{L} ; \mathrm{KH}_{2} \mathrm{PO}_{4}, 1 \mathrm{~g} / \mathrm{L} ; \mathrm{FeCl}_{2}, 0.05 \mathrm{~g} / \mathrm{L} ; \mathrm{CaCl}_{2}, 0.2 \mathrm{~g} / \mathrm{L} ; \mathrm{MgSO}_{4} .7 \mathrm{H}_{2} \mathrm{O}, 1 \mathrm{~g} / \mathrm{L} ;$ agar, $20 \mathrm{~g} / \mathrm{L}(\mathrm{pH} 7.3)$ and $\mathrm{BTB}$ reagent, $1 \mathrm{~mL} / \mathrm{L}$ (1\% in ethanol).

\section{Isolation and screening of denitrifier by enrichment methods}

The isolation of microorganisms from sludge of municipal waste water treatment plant $\left(\mathrm{NO}_{3}\right.$ Concentration of sludge- $\left.66 \mathrm{mg} / \mathrm{L}\right)$ was carried out by enrichment technique. $5 \mathrm{~mL}$ of collected samples were transferred separately into NR medium and incubated in a rotary shaker at $30^{\circ} \mathrm{C}$ and at $150 \mathrm{rpm}$ for 2days, then under aerobic condition. After two days, $5 \mathrm{~mL}$ of the sample was withdrawn from each, and transferred to fresh NR media and incubated under the same conditions. This procedure was repeated for two more times. After 6 days of incubation period, the 
samples were diluted from $10^{-3}$ to $10^{-7}$ as they were more turbid. The resulting bacterial suspensions were plated onto bromothymol blue (BTB) medium plates using spread plate technique and incubated at $30^{\circ} \mathrm{C}$ for $1-3$ days to screen denitrifiers. The colonies formed on each plate were counted using a colony counter and the Colony Forming Units (CFU) per $\mathrm{ml}$ or $\mathrm{g}$ was calculated by a standard plate count method. The blue color colonies and /or halo forming colonies on the BTB medium which indicated the presence of denitrifying microorganisms of the cultures were subjected to further screening. The colonies showing halo on the selective BTB medium were further screened by inoculating into NR medium and incubated under aerobic (Erlenmeyer flasks) and anoxic (BOD bottles) conditions separately. $10 \mathrm{~mL}$ of samples were withdrawn after 48 hours and then centrifuged at $1000 \mathrm{rpm}$ for $10 \mathrm{~min}$, and then the supernatant was analyzed for residual nitrate to select the efficient denitrifier.

\section{Culture maintenance and storage}

Nutrient Agar (NA) media was used for the growth and maintenance of bacteria. Nutrient agar media containing the components-peptone $5.0 \mathrm{~g} / \mathrm{L}$, sodium chloride $5.0 \mathrm{~g} / \mathrm{L}$, yeast extract $2.0 \mathrm{~g} / \mathrm{L}$, beef extract $1.0 \mathrm{~g} / \mathrm{L}$ and agar $15.0 \mathrm{~g} / \mathrm{L}$ was used and the initial $\mathrm{pH}$ of the medium was maintained at 7.2. The medium components were suspended in distilled water before autoclaving at $121^{\circ} \mathrm{C}$ for $20 \mathrm{~min}$ at $15 \mathrm{psi}$. The medium was then cooled prior to transferring on to sterile petri dishes. The molten agar was left to cool and solidify at room temperature. The bacteria were streaked on the agar medium and incubated at $30^{\circ} \mathrm{C}$ for 1 to 2 days and after observing growth they were stored at $4^{\circ} \mathrm{C}$. The pure cultures of bacteria were sub-cultured at regular intervals.

\section{Identification of isolate}

Based on the results of various screening tests, the bacterial isolate, designated as ASA was identified as a potential denitrifier and it was selected for further studies. The bacterial isolate was sent to Cyxton Biosolutions Pvt. Ltd., Hubballi, Karnataka, India for partial 16s RNA sequencing for its identification. The purity of strains, DNA isolation, purity and quantification, $1.5 \mathrm{~kb}$ PCR run, sequencing, blast and gene bank run, and phylogenetic tree were analyzed.

\section{Denitrification studies of a potential Isolate}

The experiments were conducted to study the effect of parameters like initial $\mathrm{pH}$ of the medium, incubation temperature, agitation speed, carbon sources, and carbon to nitrogen ratio on denitrification. In each case, sample cultures were withdrawn at regular interval of time of incubation for biomass, and nitrate analysis.

\section{Experimental design}

Design of experiments (DOEs) is a statistical technique which eliminates the systematic errors with an estimation of the experimental error and reduces the number of experiments. In this study, the central composite design (CCD) was adopted by using Design-Expert software (version 9.0). The experimental design consisted of a center point and $2 \mathrm{k}$ axial points augmented by $2 \mathrm{k}$ factorial points, where $\mathrm{k}$ represents the number of variables (Rastegar et al., 2011; Lim and Lee, 2013). The quadratic equation represents the behavior of the system.

$$
Y=\beta_{o}+\Sigma \beta_{i} X_{i}+\Sigma \beta_{i i} X_{i}^{2}+\Sigma \beta_{i j} X_{i} X_{j}
$$

Where $\mathrm{Y}$ denotes the response, $\beta_{o}$ denotes the interception coefficient, $\beta_{i}$ denotes coefficient of the linear effect, $\beta i i$ denotes coefficient of quadratic effect and $\beta_{i j}$ as the coefficient of the interaction effect. $X_{i}$ and $X_{j}$ represent the coded independent variables. From the initial screening experiments by one factor at a time method, the factors such as temperature (A), $\mathrm{pH}(\mathrm{B})$ and $\mathrm{C}$ : $\mathrm{N}$ ratio (C) was found to have a significant effect on percentage denitrification. Hence, these variables were selected as the independent variables. The model generated from regression analysis was adopted to generate contour and 3 dimensional response surface plots The coefficient of determination $\left(\mathrm{R}^{2}\right)$ represents the correlation of the model polynomial equation and its statistical significance. It was analyzed through the Ftest (Yue et al., 2007; Rastegar et al., 2011). Optimization of the process was achieved through the software developed model using desirability function.

\section{Analytical method}

Growth of the bacteria was determined by measuring the absorbance at $610 \mathrm{~nm}$ using UV-Visible Spectrophotometer (Genesys 10S). The bacterial culture was centrifuged at 10,000 rpm for 10 minutes (Laby, T-60) and supernatant sample was used for analysis of nitrate by UV-Visible Spectrophotometer (Genesys 10S) (Dhamole et al., 2007; Joshi et al., 2014). The nitrate estimation was carried out using APHA standard method and materials used were nitrite ion standard (1000 mg $\mathrm{NO}_{3}^{-} / \mathrm{L}$ ), reverse osmosis treated (RO) water samples and $\mathrm{HCl}$. Sample analysis was carried out using UV-Visible Spectrophotometer (Genesys 10S) by measuring absorbance at $220 \mathrm{~nm}$ and $275 \mathrm{~nm}$ wavelength.

\section{RESULTS AND DISCUSSION}

\section{Isolation of microorganism}

Aerobic denitrifying bacteria were isolated from sludge of municipal waste water treatment plant nearby Dharwad city, Karnataka, India. Four strains were obtained as denitrifier from the initial solid agar screening techniques. Here the colonies formed blue color and/or halo zones on BTB agar medium due to an increase in $\mathrm{pH}$ (Kim et al., 2008). These strains were individually separated and denitrification process was confirmed through the suspension cultures. Among the four strains, ASA3 showed $98 \%$ nitrate reduction and it was further sent for identification.

\section{Identification of microorganism}

The bacterial isolate was identified by $16 \mathrm{~S}$ rRNA partial genome sequencing method. The culture sample was processed for isolation and purification of genomic RNA. The isolated RNA was amplified using PCR with a combination of primers FDD2 - RPP2 as shown in Fig.1.a. After the amplification process, the $16 \mathrm{~S}$ rRNA genomic sequence was identified by adopting the Basic Local Alignment Search Tool (BLAST). The genomic sequence is presented in Fig. 1.b. Polymerase chain reaction (PCR) is a technique used to amplify the single copy or few copies of a segment of DNA across several orders of magnitude, generating thousands to millions of copies of a particular DNA sequence. The first step in a PCR cycle is the denaturation, where the hydrogen bonds holding the complementary strands of DNA together are broken. Annealing of the primers to the DNA template takes place in the second step of PCR cycle. A phylogenetic tree was constructed by the neighbor joining method as shown in Fig. 1.c. (Kim et al., 2008; Saitou et al., 1987). With closest phylogenetic identification, the isolate was identified as Enterobacter sp. NCCP-29.

Effect of physical and chemical parameters on the denitrification efficiency

The one factor at a time (OFAT) approach was implemented to choose the significant parameters and its levels for the denitrification process using isolated microorganism as given in Table 1 .

Table 1 Parameters and their range for OFAT studies

\begin{tabular}{lc}
\hline Parameters & Test range \\
\hline $\mathrm{pH}$ & $5-08$ \\
Temperature $\left({ }^{\circ} \mathrm{C}\right)$ & $20-40$ \\
Agitation speed $(\mathrm{rpm})$ & $0-250$ \\
$\mathrm{C}: \mathrm{N}$ ratio & $1: 1-3: 1$ \\
\hline
\end{tabular}

\section{Effect of initial medium $\mathrm{pH}$ on denitrification}

The effect of $\mathrm{pH}$ on denitrification was studied by growing the isolated organism in $\mathrm{NR}$ media of different initial medium $\mathrm{pH}$ with $300 \mathrm{mg} / \mathrm{L}$ initial nitrate concentration. It is evident from the Fig. 2 that at $\mathrm{pH}$ 6.5, the maximum nitrate removal of $97 \%$ was achieved and the corresponding biomass quantity observed was $0.89 \mathrm{~g} / \mathrm{L}$. The results indicate that the isolate was found to be more effective in nitrate removal at $\mathrm{pH}$ ranging from 6-7. The carbon dioxide stripping and decomposition of carbonate ions in the acidic $\mathrm{pH}$ range, resulting in carbon source deficiency, may be one of the reasons for less growth which further leads to less nitrate removal. It is known that, $\mathrm{pH}$ cannot directly affect the bacterial growth and its enzymatic activities (Campos and Flotats, 2003). At alkaline $\mathrm{pH}$, when the reaction proceeds, the alkalinity of the reaction mixture increases which may reduce the activity of the microorganisms. 
(a)

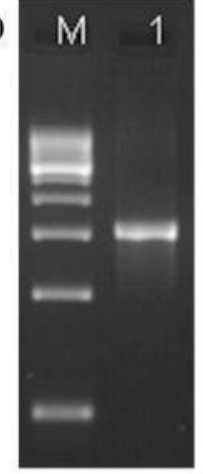

(b) ATGCAAGTCGAACGGTAGCACATAGAGCTTGCTCTCGGGTGACGAGTGGCGGACGGGTGAGTAATGTCTGGGAAACTGCCTO

b) ATGGAGGGGGATAACTACTGGAAACGGTAGCTAATACCGCATAACGTCGCAAGACCAAAGAGGGGGACCTTCGGGCCTCTTO CCATCAGATGTGCCCAGATGGGATTAGCTAGTAGGTGGGGTAACGGCTCACCTAGGCGACGATCCCTAGCTGGTCTGAGAGG ATGACCAGCCACACTGGAACTGAGACACGGTCCAGACTCCTACGGGAGGCAGCAGTGGGGAATATTGCACAATGGGCGCAA GCCTGATGCAGCCATGCCGCGTGTATGAAGAAGGCCTTCGGGTTGTAAAGTACTTTCAGCGGGGAGGAAGGTGTTGTGGTTA ATAACCACAGCAATTGACGTTACCCGCAGAAGAAGCACCGGCTAACTCCGTGCCAGCAGCCGCGGTAATACGGAGGGTGCAA GCGTTAATCGGAATTACTGGGCGTAAAGCGCACGCAGGCGGTCTGTCAAGTCGGATGTGAAATCCCCGGGCTCAACCTGGGA ACTGCATTCGAAACTGGCAGGCTAGGAGTCTTGTAGAGGGGGGTAGAATTCCAGGTGTAGCGGTGAAATGCGTAGAGATCTO GAGGAATACCGGTGGCGAAGGCGGCCCCCTGGACAAAGACTGACGCTCAGGTGCGAAAGCGTGGGGAGCAAACAGGATTAG ATACCCTOGTAOTCCACGCCOTAAACGATGTCGATTTGG TCOACCTOCCTGOGOAOTACOGCCGCAAGOTTAAACT TCGACCGCCTGGGGAGTACGGCCGCAAGGTTAAAACTCAAATGAATTGACGGGGGCCCGCACAAGCGGTGGAGCATGTGGT TAATTCGATGCAACGCGAAGAACCTTACCTGGTCTTGACATCCACAGAACTTTCCAGAGATGGATTGGTGCCTTCGGGAACTO TGAGACAGGTGCTGCATGGCTGTCGTCAGCTCGTGTTGTGAAATGTTGGGTTAAGTCCCGCAACGAGCGCAACCCTTATCCTT TGTTGCCAGCGGTCAGGCCGGGAACTCAAAGGAGACTGCCAGTGATAAACTGGAGGAAGGTGGGGATGACGTCAAGTCATC ATGGCCCTTACGACCAGGGCTACACACGTGCTACAATGGCGCATACAAAGAGAAGCGACCTCGCGAGAGCAAGCGGACCTC ATAAAGTGCGTCGTAGTCCGGATTGGAGTCTGCAACTCGACTCCATGAAGTCGGAATCGCTAGTAATCGTAGATCAGAATGCT ACGGTGAATACGTTCCCGGGCCTTGTACACACCGCCCGTCACACCATGGGAGTGGGTTGCAAAAGAAGTAGGTAGCTTAACC TTCGGGA

(c)

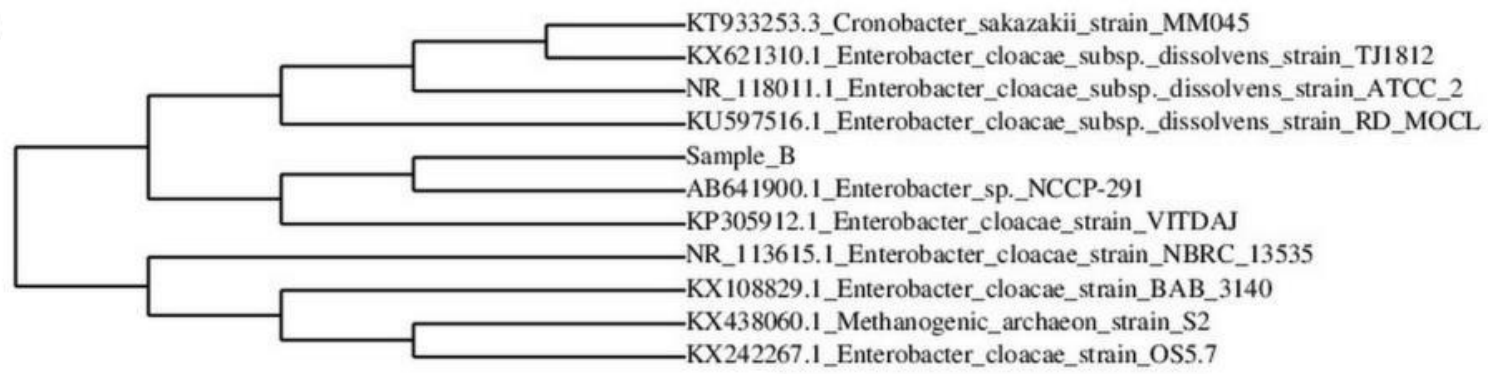

Figure 1 (a) Amplification profile of the strain, (b) 16S rRNA gene sequence of the bacterial isolate (c) Phylogenetic tree based on a comparison of the 16S rRNA gene sequence

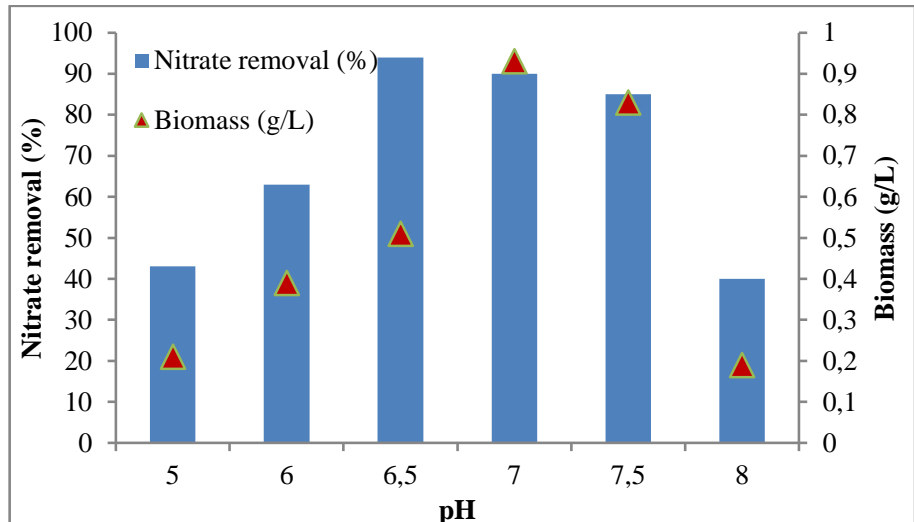

Figure 2 Effect of initial medium $\mathrm{pH}$ on percentage of nitrate removal by Enterobacter sp. NCCP-29

\section{Effect of incubation temperature on percentage denitrification}

The effect of incubation temperature on denitrification by isolated microorganism was studied by incubating in NR media at different temperatures of 20,25,30, 35 and $40^{\circ} \mathrm{C}$. The NR media with the initial nitrate supplement of $300 \mathrm{ppm}$ was inoculated with isolated strain and incubated in rotary incubator shaker at the above mentioned temperatures. It is evident from the Fig. 3 that, isolate showed maximum growth and nitrate removal efficiency at an incubation temperature of $30^{\circ} \mathrm{C}$. At this temperature, biomass yield was $0.91 \mathrm{~g} / \mathrm{L}$. At lower temperatures i.e., 20 and $25^{\circ} \mathrm{C}$, the biomass yield obtained were $0.21 \mathrm{~g} / \mathrm{L}$ and $0.23 \mathrm{~g} / \mathrm{L}$, respectively. The corresponding percentages of nitrate removals were found to be $47 \%$, and $54 \%$, respectively. At higher temperatures, i.e., $35^{\circ} \mathrm{C}$ and $40^{\circ} \mathrm{C}$, the percentage denitrification observed was $71 \%$ and $65 \%$ with corresponding biomass yield of $0.45 \mathrm{~g} / \mathrm{L}$ and $0.52 \mathrm{~g} / \mathrm{L}$, respectively.

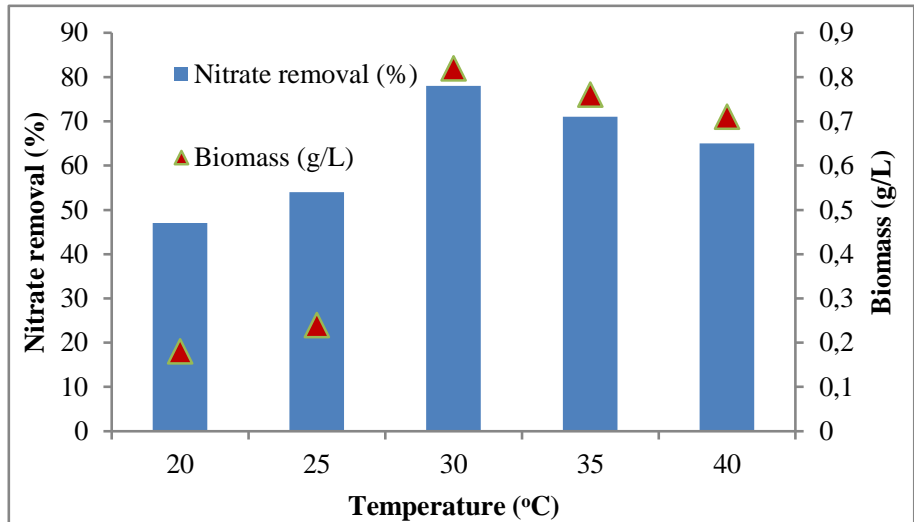

Figure 3 Effect of incubation temperature on percentage nitrate removal by an Enterobacter sp. NCCP-29

Variation in temperature affects the folding of enzyme structure, which further alters the enzyme kinetics. At a certain temperature, the arrangement of the proper catalytic site will be formed and at that particular temperature, enzyme activity is maximum. Wang et al., (1995) reported that at $30^{\circ} \mathrm{C}$, the culture reduced nitrate optimally and its Arrhenius-type expressions were used in explaining the effect of temperature on each of the parameters. Su et al., (2001) reported that at $30^{\circ} \mathrm{C}$ after $20 \mathrm{~h}$, the concentration of nitrate decreased rapidly in the presence of Pseudomonas stutzeri.

\section{Effect of agitation speed on denitrification}

The effect of mixing on denitrification was studied by varying the agitation speed of the flasks containing the NR medium with an initial nitrate supplement of 300 $\mathrm{mg} / \mathrm{L}$. The flasks were inoculated with isolate culture and incubated at $30^{\circ} \mathrm{C}$ at different agitation speeds at $0 \mathrm{rpm}$ (static culture), 50, 100, 150, 200 and $250 \mathrm{rpm}$. It is evident from Fig. 4 that with an increase in agitation speed, no significan change in nitrate removal until $200 \mathrm{rpm}$ was observed. In the present study, a maximum of $98 \%$ nitrate removal was achieved in the culture kept at an agitation speed of $150 \mathrm{rpm}$ in an incubator shaker. The corresponding biomass quantity produced was $0.98 \mathrm{~g} / \mathrm{L}$. At agitation speed of $250 \mathrm{rpm}$, a decrease in nitrate removal, as well as biomass growth, was observed. In this condition, the observed percentage denitrification was $56 \%$ and the amount of biomass produced was 0.57 $\mathrm{g} / \mathrm{L}$. Above $200 \mathrm{rpm}$ agitation speed, it was observed that, there is reduction in nitrate removal due to the rupture of cells. Liang et al., (2011) reported that 420 $\mathrm{mg} / \mathrm{L} \mathrm{NO}_{3}^{-} \mathrm{N}$ was completely removed within $30 \mathrm{~h}$ at $160 \mathrm{rpm}$ and a further 
increase in agitation speed did not have much effect on the nitrate removal efficiency.

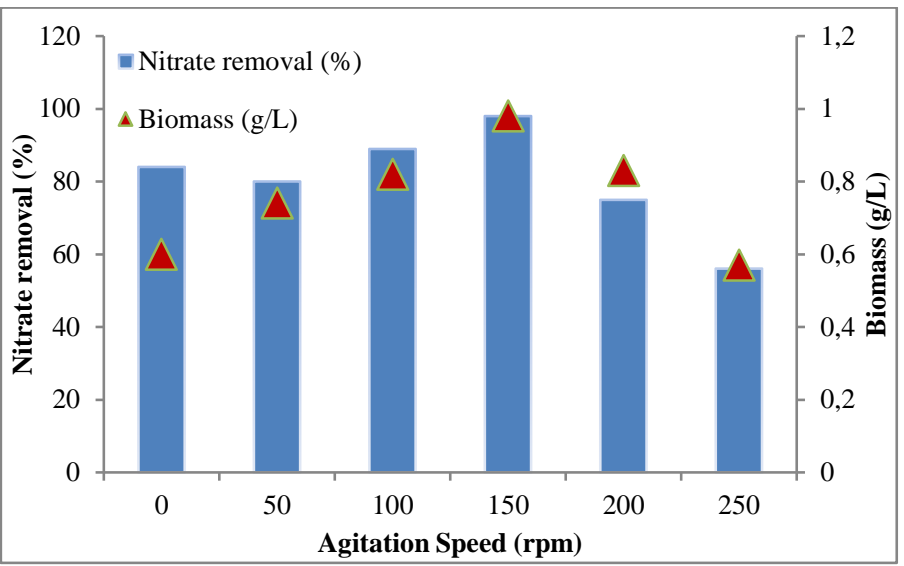

Figure 4 Effect of agitation speed on percentage nitrate removal by Enterobacter sp. NCCP-29

\section{Effect of different carbon sources on denitrification}

In the present study, different carbon sources included in this study were dextrose, ethanol, sodium acetate, sodium succinate and methanol. It is observed from the Fig. 5 that, the maximum nitrate removal of $95 \%$ with the corresponding biomass yield of $0.98 \mathrm{~g} / \mathrm{L}$ was obtained in the medium supplemented with sodium succinate as a carbon source. The nitrate removal efficiency was considerably less when dextrose and methanol were used as carbon sources. In these cases, nitrate removal was $72 \%$ and $39 \%$, respectively. The corresponding biomass quantities produced were $0.33 \mathrm{~g} / \mathrm{L}$ and $0.19 \mathrm{~g} / \mathrm{L}$, respectively.

It was observed that maximum nitrate removal could be achieved in the cases of medium supplemented with sodium acetate, sodium succinate and ethanol as carbon sources. Sodium succinate and sodium acetate are the intermediate molecules of the TCA cycle in the metabolic activity and hence, they can easily be utilized by bacteria as electron donors. The presence of these compounds enhances the microbial growth, which in turn resulted in more nitrate removal. Choice of the carbon source is very important to avoid the incomplete denitrification because higher levels of nitrite accumulation exhibit toxicity for many bacteria. Acetate donates electrons closer to nitrate reductase, in the upstream region of the respiratory chain to either cytochrome or ubiquinone (Van Rijn et al., 1996), but acetate as carbon source stimulates denitrification in activated sludge samples (Eilersen et al., 1995).

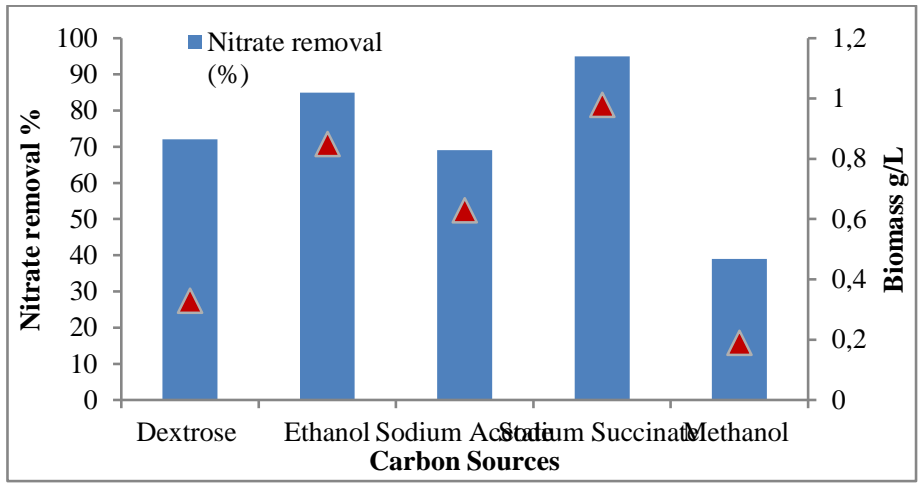

Figure 5 Effect of different carbon sources on nitrate removal by Enterobacter $s p$ NCCP-29

\section{Effect of carbon to nitrogen ratio on denitrification}

In the present study, carbon to nitrogen ratios 3:1 (3), 2:1(2) and 1:1(1) for the carbon sources of ethanol (a), sodium acetate (b) and for sodium succinate (c) were considered to prepare NR media, for inoculation with isolate. While preparing NR media, carbon concentration was only altered, and nitrate concentration was kept constant. It is evident from Fig. 6 that, for all individual carbon sources, 3:1 ratio was found to be the optimum ratio for nitrate removal. At this ratio, the maximum nitrate removal of $98 \%$ was achieved for the medium containing sodium succinate. The corresponding biomass yield obtained was $1.29 \mathrm{~g} / \mathrm{L}$.

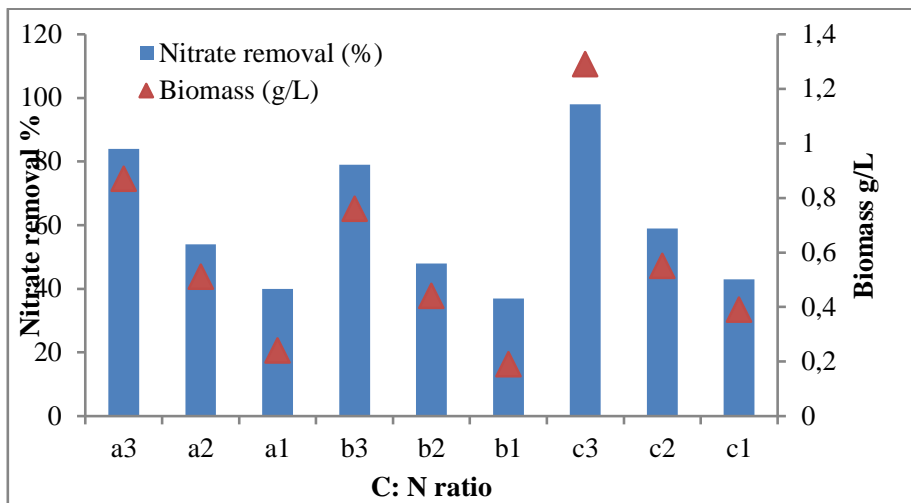

Figure 6 Effect of different carbon sources and carbon to nitrogen ratio on percentage nitrate removal by Enterobacter $s p$. NCCP-29

Elefsiniotis et al., (2004) and Liang et al., (2011) have reported that, at an insufficient carbon concentration, the electron flow is too low to provide enough energy for cell growth and causes accumulation of intermediate such as nitrite When excess carbon substrates are added, it may inhibit the growth of the bacteria, which in turn delay the denitrification process.

\section{Response Surface Methodology (RSM) studies}

Central Composite Design (CCD) was adopted to optimize the concentration of three independent variables temperature, $\mathrm{pH}$ and $\mathrm{C}: \mathrm{N}$ ratio (Table 2). The behavior of the system was explained with the coded quadratic equation

$\mathrm{Y}=-49.6+28.07 \mathrm{~A}+1.94 \mathrm{~B}+12.9 \mathrm{C}-2.776 \mathrm{AXA}-0.727 \mathrm{BXB}-$

6.39 $\mathrm{CXC}+0.1700 \mathrm{AXB}+2.300 \mathrm{AXC}+0.325 \mathrm{BXC}$

Table 2 Coded significant parameters and their actual levels for optimization by CCD

\begin{tabular}{lccccc}
\hline & \multicolumn{5}{c}{ Levels } \\
\cline { 2 - 6 } Factors & $-\alpha$ & -1 & 0 & +1 & $+\alpha$ \\
\hline $\mathrm{pH}$ & 2.29 & 4 & 6.5 & 9 & 10.70 \\
Temperature $\left({ }^{0} \mathrm{C}\right)$ & 13.18 & 20 & 30 & 40 & 46.81 \\
$\mathrm{C}: \mathrm{N}$ ratio & 1.31 & $2: 1$ & $3: 1$ & $4: 1$ & 4.68
\end{tabular}

Table 3 Full factorial central composite design matrix and their observed response

\begin{tabular}{cccccc}
\hline $\begin{array}{c}\text { Run } \\
\text { order }\end{array}$ & pH & Temperature & $\begin{array}{c}\text { C:N } \\
\text { Ratio }\end{array}$ & $\begin{array}{c}\text { Y=\% of } \\
\text { removal } \\
\text { (Actual) }\end{array}$ & $\begin{array}{c}\text { Y=\% of } \\
\text { removal } \\
\text { (Predicted) }\end{array}$ \\
\hline 1 & 4.0 & 20.0 & $2: 1$ & 75 & 73.22 \\
2 & 9.0 & 20.0 & $2: 1$ & 68 & 73.13 \\
3 & 4.0 & 40.0 & $2: 1$ & 47 & 51.38 \\
4 & 9.0 & 40.0 & $2: 1$ & 78 & 68.29 \\
5 & 4.0 & 20.0 & $4: 1$ & 42 & 53.74 \\
6 & 9.0 & 20.0 & $4: 1$ & 79 & 76.65 \\
7 & 4.0 & 40.0 & $4: 1$ & 48 & 45.90 \\
8 & 9.0 & 40.0 & $4: 1$ & 81 & 84.81 \\
9 & 2.29 & 30.0 & $3: 1$ & 37 & 30.96 \\
10 & 10.70 & 30.0 & $3: 1$ & 62 & 64.44 \\
11 & 6.5 & 13.18 & $3: 1$ & 89 & 81.96 \\
12 & 6.5 & 46.81 & $3: 1$ & 67 & 70.46 \\
13 & 6.5 & 30.0 & $1.31: 1$ & 78 & 79.94 \\
14 & 6.5 & 30.0 & $4.68: 1$ & 83 & 77.46 \\
15 & 6.5 & 30.0 & $3: 1$ & 97 & 96.77 \\
16 & 6.5 & 30.0 & $3: 1$ & 98 & 96.77 \\
17 & 6.5 & 30.0 & $3: 1$ & 98 & 96.77 \\
18 & 6.5 & 30.0 & $3: 1$ & 96 & 96.77 \\
19 & 6.5 & 30.0 & $3: 1$ & 94 & 96.77 \\
20 & 6.5 & 30.0 & $3: 1$ & 98 & 96.77 \\
\hline & & & & &
\end{tabular}

Experiments were carried out according to the design as presented in Table 3 and actual and predicted values were compared. Actual values were the response obtained from the particular experimental run and predicted response were values determined by approximating functions employed by the model and are presented in Fig. 7. 
Where Y represents the \% removal of nitrate, -49.6 is the interception coefficient, 28.07,1.94 and 12.9 is coefficient of the linear effect, $-2.77,-0.727$ and -6.39 is the coefficient of quadratic effect and $0.17,2.3$ and 0.325 is the coefficient of interaction effect. A, B and $\mathrm{C}$ represent the independent variables $\mathrm{pH}$, temperature and $\mathrm{C}: \mathrm{N}$ ratio respectively. From the initial screening experiments by one factor at a time method, the factors such as $\mathrm{pH}(\mathrm{A})$, temperature (B), and $\mathrm{C}$ : $\mathrm{N}$ ratios $(\mathrm{C})$ were found to have significant effect on percentage denitrification. Hence, these variables were chosen as the independent variables. To maximize the percentage denitrification, these variables were optimized using response surface methodology. A $2^{3}$ factorial design augmented by 6 axial points $(\alpha=2)$ was implemented in 20 experiments where in the effect of each compound on denitrification rate was taken as a response. A total number of 20 experiments were conducted in duplicates to establish the relationship between independent variables $(\mathrm{pH}$, temperature and $\mathrm{C}: \mathrm{N}$ ratio) and dependent variable/response (percentage denitrification). Details of the design have been presented in Table 2 .

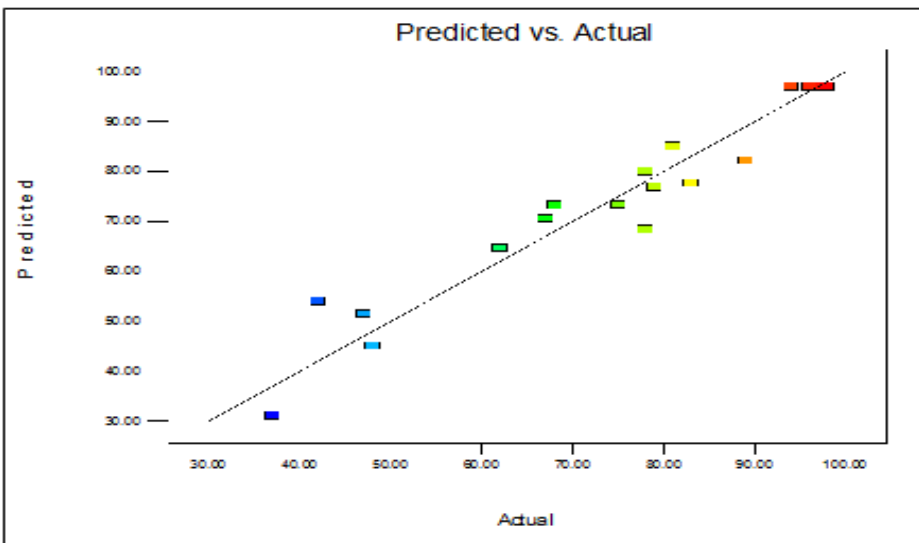

Figure 7 Comparison of experimental and predicted values for nitrate removal

Adequacy of the model was tested by determining the significant variables with ANOVA. The results of ANOVA were tested by means of specified classification difference. It consists of classified and cross-classified statistical results analyzed by F-test developed by Fisher. F-value is defined as the ratio of the mean square of regression to the mean square residual or error (Anupam et al., 2011; Nejad et al., 2011). The $R^{2}$ and $R^{2}$ (adj) were evaluated to test the global fit of the model. The value of $\mathrm{R}^{2}$ was found to be $93.8 \%$ and hence the model did not explain only $6.2 \%$ of the total variability. The value of $\mathrm{R}^{2}$ (adj) was $88.35 \%$ deviates only by $6.2 \%$ from the $\mathrm{R}^{2}$ value. This reveals that the model is highly significant and there is only a meagre chance to incorporate any insignificant terms in the model. The significance of individual coefficients and its interactions are determined by $\mathrm{P}$ value. It is used to assess the significance of coefficients, smaller P-value $(<0.05)$ and a larger regression indicates the significant effect of the variables on the response variable (Nejad et al., 2011; Anupam et al., 2011). If P-value is less than 0.05 , then it is statistically significant at a confidence level of 98\% (Anupam $\boldsymbol{e t}$ al., 2011). Square $(\mathrm{P}<0.001)$ and interaction $(\mathrm{P}<0.001)$ effects of all the three variables temperature, $\mathrm{pH}$ and $\mathrm{C}: \mathrm{N}$ ratio had a significant influence on the percentage denitrification. Regression analysis of the data resulted in the polynomial equation which is given below. Regression equation in uncoded units

$Y=\%$ removal $=-49.6+28.07 p H+1.94$ Temp $+12.9 \mathrm{C}: \mathrm{N}-2.776 \mathrm{pH} \times \mathrm{pH}-0.727$ Temp $\times$ Temp $-6.39 C: N \times C: N+0.1700 p H \times T e m p+2.300 p H \times C: N+0.325 T e m p \times C: N$ (3)

Table 4 ANOVA test for response function of nitrate removal

\begin{tabular}{lccccc}
\hline Source & $\begin{array}{c}\text { Sum of } \\
\text { squares }\end{array}$ & Df & $\begin{array}{c}\text { Mean } \\
\text { square }\end{array}$ & F Value & $\begin{array}{c}\text { P } \\
\text { Value }\end{array}$ \\
\hline Model & $\mathbf{7 0 5 8 . 4 9}$ & $\mathbf{9}$ & $\mathbf{7 8 4 . 2 8}$ & $\mathbf{1 7 . 0 0}$ & $<\mathbf{0 . 0 0 0 1}$ \\
A-pH & $\mathbf{1 3 5 5 . 2 3}$ & $\mathbf{1}$ & $\mathbf{1 3 5 5 . 2 3}$ & $\mathbf{2 9 . 3 8}$ & $\mathbf{0 . 0 0 0 3}$ \\
B-Temp & 161.75 & 1 & 161.75 & 3.51 & 0.0906 \\
C-C:N & 6.74 & 1 & 6.74 & 0.15 & 0.7104 \\
AB & 144.50 & 1 & 144.50 & 3.13 & 0.1072 \\
AC & $\mathbf{2 6 4 . 5 0}$ & $\mathbf{1}$ & $\mathbf{2 6 4 . 5 0}$ & $\mathbf{5 . 7 3}$ & $\mathbf{0 . 0 3 7 7}$ \\
BC & 84.50 & 1 & 84.50 & 1.83 & 0.2057 \\
A $^{\wedge}$ & $\mathbf{4 3 3 8 . 1 4}$ & $\mathbf{1}$ & $\mathbf{4 3 3 8 . 1 4}$ & $\mathbf{9 4 . 0 5}$ & $<\mathbf{0 . 0 0 0 1}$ \\
$\mathrm{B}^{\wedge} 2$ & 762.47 & 1 & 762.47 & 16.53 & 0.0023 \\
$\mathrm{C}^{\wedge} 2$ & 588.42 & 1 & 588.42 & 12.76 & 0.0051 \\
Residual & 461.26 & 10 & 46.13 & & \\
Pure Error & 12.83 & 5 & 2.57 & & \\
Cor Total & 7519.75 & 19 & & & \\
$\mathrm{R}^{2}=93.87 \%$ & Adj $\mathrm{R}^{2}=88.35 \%$ & Predicted $\mathrm{R}^{2}=49.86 \%$ & \\
\hline \multicolumn{7}{c}{}
\end{tabular}

The positive coefficients of variables indicate that they have a synergistic effect on rate of denitrification whereas the negative coefficients of variables indicate an antagonistic effect on the rate of denitrification. The results of the ANOVA are given in Table 4. P-value of $\mathrm{pH}(\mathrm{A})$ is less than 0.05 , also the $\mathrm{P}$-value of $\mathrm{AC}$ is also less than 0.05 . These are said to play a significant role in denitrification. These are said to be interacting, so the response surface plots obtained are elliptical in nature (Fig.9) while other response surface plots obtained were circular in nature (Fig. 8 \& 10).

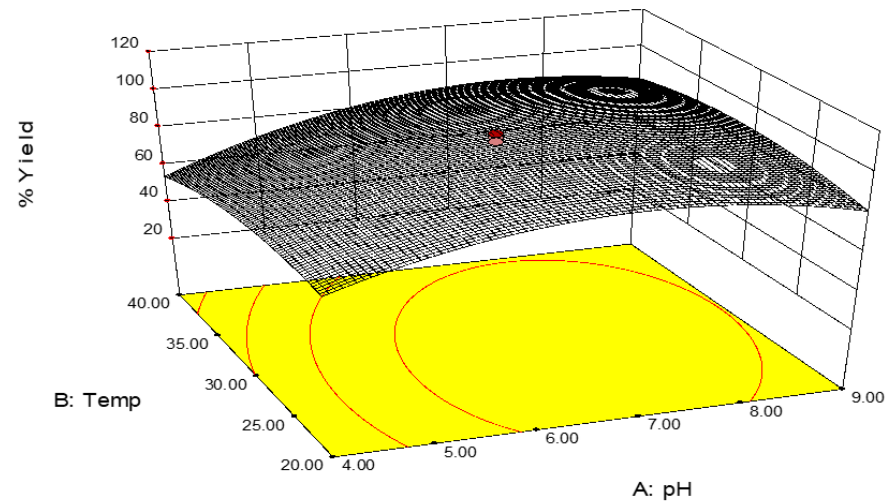

Figure 8 Response surface plot for temperature and $\mathrm{pH}$ on percentage denitrification

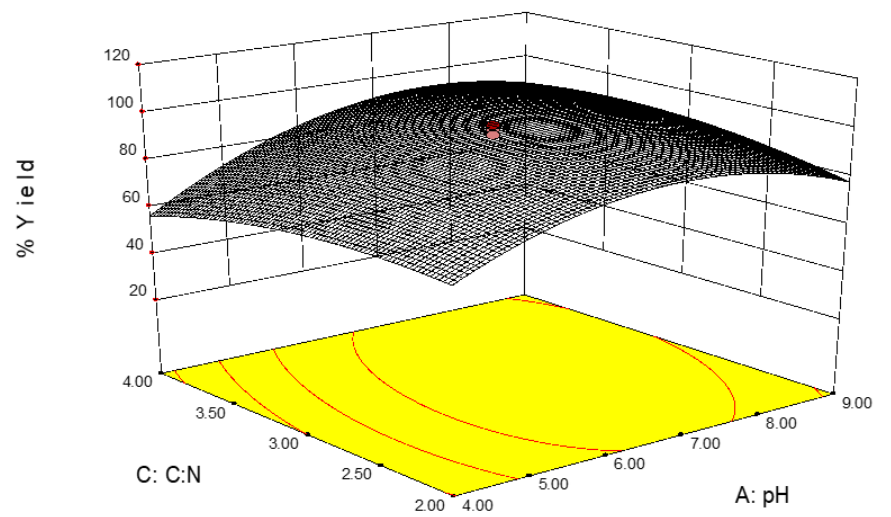

Figure 9 Response surface plot for the effect $\mathrm{C}: \mathrm{N}$ ratio and $\mathrm{pH}$ on percentage denitrification

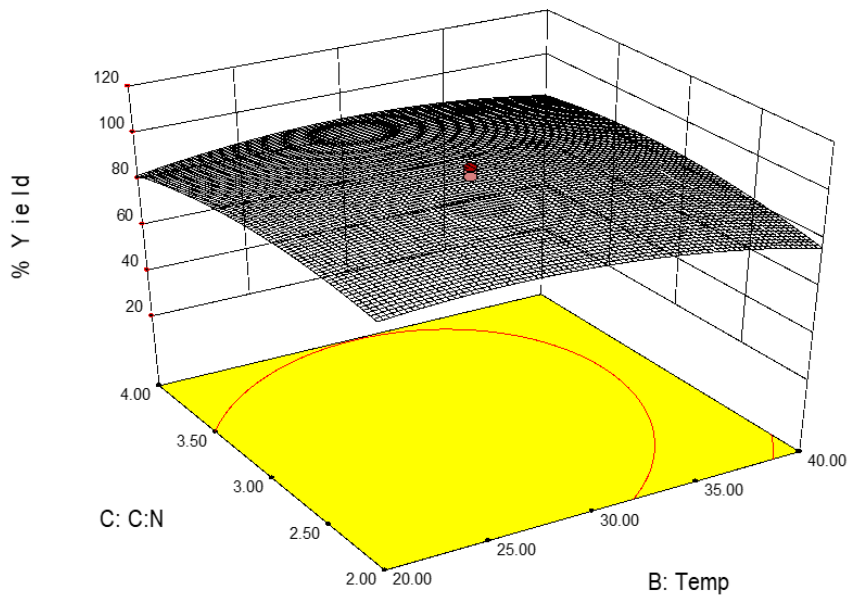

Figure 10 Response surface plot for the effect $\mathrm{C}$ : $\mathrm{N}$ and temperature on percentage denitrification

Fig 8, 9, 10 represent the contour plots and three dimensional response for the parameters $(\mathrm{pH}$, temperature and $\mathrm{C}: \mathrm{N}$ ratio) which affect the denitrification efficiency. It can be seen from the figures that, the percentage denitrification decreased beyond the neutral range of $\mathrm{pH}$, at very low and very high temperatures and at higher $\mathrm{C}: \mathrm{N}$ ratio. Maximum percentage denitrification was obtained at a temperature of $30^{\circ} \mathrm{C}, \mathrm{pH} 6.5$ and $\mathrm{C}: \mathrm{N}$ ratio of $3: 1$. These optimized values were validated by conducting experiments using these conditions, the percentage 
denitrification was found to be $98 \%$. These results are in good agreement with the predicted results and confirmed adequacy of the model.

\section{CONCLUSION}

In this study, a potential novel denitrifying bacterium was isolated from sludge of municipal waste water treatment plant and identified as Enterobacter $s p$. NCCP 29. The bacterium showed the significant nitrate removal without nitrite accumulation. The bacterium, Enterobacter sp. NCCP-29 showed highest nitrate removal capability of $98 \%$ at $\mathrm{pH} 6.5,150 \mathrm{rpm}$ agitation speed, the temperature of $30^{\circ} \mathrm{C}$, for sodium succinate as a carbon source and for $3: 1$ as $\mathrm{C}: \mathrm{N}$ ratio. Moreover, the denitrification activity of the bacterium was not much affected by the increase in agitation speed up to $200 \mathrm{rpm}$, which indicated the aerobic denitrification process of the bacterium. The developed model with correlation based on the experimental results of the CCD and RSM were useful to optimize the process parameters for the denitrification process. These results suggest that Enterobacter sp. NCCP-29 may be a prospective candidate for nitrate removal under aerobic condition in waste water treatment.

Acknowledgment: The authors wish to thank, Vision Group on Science and Technology VGST (GRD 478), Government of Karnataka, Bangaluru for funding the project and the Management, the Principal and Department of Chemica Engineering, SDMCET for the support and encouragement to carry out the work at the department. We also thank Department of Biotechnology Engineering, NMAMIT, Nitte for their kind support.

\section{REFERENCES}

Aghamohammadi, N., bin Abdul Aziz, H., Isa, M. H., \& Zinatizadeh, A. A. (2007) Powdered activated carbon augmented activated sludge process for treatment of semi-aerobic landfill leachate using response surface methodology. Bioresource Technology, 98(18)

https://dx.doi.org/10.1016/j.biortech.2006.11.037

3570-3578.

Ahmadi, M., Vahabzadeh, F., Bonakdarpour, B., Mofarrah, E., \& Mehranian, M (2005). Application of the central composite design and response surface methodology to the advanced treatment of olive oil processing wastewater using Fenton's peroxidation. Journal of Hazardous Materials, 123(1), 187-195. https://dx.doi.org/10.1016/j.jhazmat.2005.03.042

Anupam, K., Dutta, S., Bhattacharjee, C., \& Datta, S. (2011). Adsorptive remova of chromium (VI) from aqueous solution over powdered activated carbon: Optimisation through response surface methodology. Chemical Engineering Journal, 173(1), 135-143. https://dx.doi.org/10.1016/j.cej.2011.07.049

Bas, D., \& Boyac1, I. H. (2007). Modeling and optimization I: Usability of response surface methodology. Journal of food engineering, 78(3), 836-845. https://dx.doi.org/10.1016/j.jfoodeng.2005.11.024

Box, G. E., \& Draper, N. R. (1987). Empirical model-building and response surfaces (Vol. 424). New York: Wiley.

Campos, E., \& Flotats, X. (2003). Dynamic simulation of $\mathrm{pH}$ in anaerobic processes. Applied biochemistry and biotechnology, 109(1-3), 63-76. https://dx.doi.org/10.1385/abab:109:1-3:63

Dedong Kong, Wenbing Li, Yale Deng, Yunjie Ruan, Guangsuo Chen, Jianhai Yu \& Fucheng Lin (2018). Denitrification-Potential Evaluation and Nitrate-RemovalPathway Analysis of Aerobic Denitrifier Strain Marinobacter $\begin{array}{llrr}\text { hydrocarbonoclasticus } & \text { RAD-2, } & \text { Water } & 10,\end{array}$ https://dx.doi.org/10.3390/w10101298

Dhamole, P. B., Nair, R. R., D’Souza, S. F., \& Lele, S. S. (2007). Denitrification of high strength nitrate waste. Bioresource technology, 98(2), 247-252. https://dx.doi.org/10.1016/j.biortech.2006.01.019

Elefsiniotis, P., \& Li, D. (2006). The effect of temperature and carbon source on denitrification using volatile fatty acids. Biochemical Engineering Journal, 28(2), 148-155. https://dx.doi.org/10.1016/j.bej.2005.10.004

Galloway, J. N., Townsend, A. R., Erisman, J. W., Bekunda, M., Cai, Z., Freney, J. R.,\& Sutton, M. A. (2008). Transformation of the nitrogen cycle: recent trends, questions, and potential solutions. Science, 320(5878), 889-892. https://dx.doi.org/10.1126/science.1136674

Joshi, K., Joseph, J., Srinikethan, G., \& Saidutta, M. B. (2014). Isolation and characterization of Psedomonas Syringae for nitrate removal under aerobic conditions. Journal of Biochemical Technology, 5(2), 693-697.

Kim, M., Jeong, S. Y., Yoon, S. J., Cho, S. J., Kim, Y. H., Kim, M. J.,\& Lee, S. J. (2008). Aerobic denitrification of Pseudomonas putida AD-21 at different C/N ratios. Journal of Bioscience and Bioengineering, 106(5), 498-502. https://dx.doi.org/10.1263/jbb.106.498

Liang, S. C., Zhao, M., Lu, L., Wang, C. L., Zhao, L. Y., \& Liu, W. J. (2011) Isolation and characteristic of an aerobic denitrifier with high nitrogen removal efficiency. African Journal of Biotechnology, 10(52), 10648 10656. https://dx.doi.org/10.5897/ajb11.569

Lim, S., \& Lee, K. T. (2013). Optimization of supercritical methanol reactive extraction by Response Surface Methodology and product characterization from
Jatropha curcas L. seeds. Bioresource technology, 142, 121-130. https://dx.doi.org/10.1016/j.biortech.2013.05.010

Matsuzaka, E., Nomura, N., Nakajima-Kambe, T., Okada, N., \& Nakahara, T. (2003). A simple screening procedure for heterotrophic nitrifying bacteria with oxygen-tolerant denitrification activity. Journal of Bioscience and Bioengineering, 95(4), 409-411. $\quad$ https://dx.doi.org/10.1016/s13891723(03)80077-4

Nejad, H. H., \& Kazemeini, M. (2012). Optimization of platinum extraction by trioctylphosphine oxide in the presence of alkaline-metal salts. Procedia Engineering, 42, 1302-1312. https://dx.doi.org/10.1016/j.proeng.2012.07.522

Rastegar, S. O., Mousavi, S. M., Shojaosadati, S. A., \& Sheibani, S. (2011). Optimization of petroleum refinery effluent treatment in a UASB reactor using response surface methodology. Journal of hazardous materials, 197, 26-32. https://dx.doi.org/10.1016/j.jhazmat.2011.09.052

Rezaee, A., Godini, H., Dehestani, S., \& Kaviani, S. (2010). Isolation and characterization of a novel denitrifying bacterium with high nitrate removal: Pseudomonas Stutzeri. Iranian Journal of Environmental Health Science \& Engineering, 7(4), 313.

Saitou, N., \& Nei, M. (1987). The neighbor-joining method: a new method for reconstructing phylogenetic trees. Molecular biology and evolution, 4(4), 406 425. https://dx.doi.org/10.1093/oxfordjournals.molbev.a040454

Su, J. J., Liu, B. Y., \& Liu, C. Y. (2001). Comparison of aerobic denitrification under high oxygen atmosphere by Thiosphaera pantotropha ATCC 35512 and Pseudomonas stutzeri SU2 newly isolated from the activated sludge of a piggery wastewater treatment system. Journal of applied microbiology, 90(3), 457-462. https://dx.doi.org/10.1046/j.1365-2672.2001.01265.x

Van Rijn, J. (1996). The potential for integrated biological treatment systems in recirculating fish culture-a review. Aquaculture, 139(3-4), 181-201. https://dx.doi.org/10.1016/0044-8486(95)01151-x

Vitousek, P. M., Aber, J. D., Howarth, R. W., Likens, G. E., Matson, P. A., Schindler, D. W., ... \& Tilman, D. G. (1997). Human alteration of the global nitrogen cycle: sources and consequences. Ecological applications, 7(3), 737-750. https://dx.doi.org/10.1890/1051-0761(1997)007[0737:haotgn]2.0.co;2

Wang, J. H., Baltzis, B. C., \& Lewandowski, G. A. (1995). Fundamental denitrification kinetic studies with Pseudomonas denitrificans. Biotechnology and bioengineering, 47(1), 26-41. https://dx.doi.org/10.1002/bit.260470105

Wang, X. M., \& Wang, J. L. (2013). Nitrate removal from groundwater using solidphase denitrification process without inoculating with external microorganisms. International Journal of Environmental Science and Technology, 10(5), 955-960. https://dx.doi.org/10.1007/s13762-013-0236-x

Yang, K., Yu, Y., \& Hwang, S. (2003). Selective optimization in thermophilic acidogenesis of cheese-whey wastewater to acetic and butyric acids: partial acidification and methanation. Water Research,37(10), 2467-2477. https://dx.doi.org/10.1016/S0043-1354(03)00006-X

Yue, Z. B., Yu, H. Q., Harada, H., \& Li, Y. Y. (2007). Optimization of anaerobic acidogenesis of an aquatic plant, Canna indica L., by rumen cultures. Water research, 41(11), 2361-2370. https://dx.doi.org/10.1016/j.watres.2007.02.031

Zinatizadeh, A. A. L., Younesi, H., Bonakdari, H., Pirsaheb, M., Pazouki, M., Najafpour, G. D., \& Isa, M. H. (2009). Effects of process factors on biological activity of granular sludge grown in an UASFF bioreactor. Renewable Energy, 34(5), 1245-1251. https://dx.doi.org/10.1016/j.renene.2008.10.013 Zumft, W. G. (1997). Cell biology and molecular basis of denitrification. Microbiology and molecular biology reviews, 61(4), 533-616. 